\title{
NIGERIA: \\ Democracy and Security. The Role of the Military, 1999-2018
}

\author{
Abdulsalami M. DEJI
}

\begin{abstract}
The prolonged military incursion in Nigerian politics in favour of the oligarchy brought agitation for the democratic rule; it exacerbated ethnicity and created the fear of domination of the minority by the majority. The advent of democracy ushered in a new breath of life and took Nigerians away from the shackle of military oppression to civilian rule. The democratic rule became a mirage as a result of prevalent insecurity in Nigeria. Unfortunately, efforts to bring lasting peace to all sections of the country have not yielded positive result till date. The failure has resulted in general insecurity among ethnic groups consequent upon which ethnic militia emerged among groups for the defence of their members or individual groups. The phenomenon also resulted from the unequal distribution of wealth by the military Junta. This trend resulted in general perennial crises. Even the democracy was instituted, the warlords of the various militia groups constituted themselves into obstacles to democratic institutions. Even the democratic institutions deviated from using security agencies for the security of other citizens. Instead, security agencies became politicised, which has remained the dominant factor hindering the actualisation of dividends of democracy. And today, needless to even say that insecurity or unrest has crippled socio-political and economic spheres of life of the nation. This paper examines democracy and security in Nigeria, the security challenges in various regions of Nigeria and the contributions made by the military institutions in maintaining peace and security under democratic rule since 1999 up to 2017.
\end{abstract}

Abdulsalami M. DEJI, PhD

Department of History \& Diplomatic

Studies, Faculty of Arts

Taraba State University, Jalingo

e-mail: dejfat2009@tsuniversity.ed.ng

Conflict Studies Quarterly

Issue 28, July 2019, pp. 33-45

DOI:10.24193/csq.28.3

Published First Online: 28/06/2019
Keywords: Democracy, Security, Military and Development.

\section{Introduction}

There are many systems of government in the world today aside democracy which many people regard as the most popular system of government. Democracy entrenches the rule of law as the pillar of ideal society in any democratic setting (Schlosberg, 2013). 
However, the capacity to effective democratic system that will translate to development lies with the operators in any society. That is why democracy is not regarded as the only credible means of bringing development to the society.

It has been argued that, there are many countries of the world that are not practicing democracy. Yet, development is visible in those areas. The examples of the areas include Saudi Arabia, United Arab Emirate, Morocco, etc. The upsurge in democracy began in the 1970s. For instance, only 45 of the world's 151 countries could be counted as democratic nations up to 1973 (Fukuyama, 2012, p. 1). As of the end of 2016, 97 out of 167 notable countries were democracies and only 21 were autocracies. The analysis shows that democracy spread rapidly as the Soviet Union crumbled in 1989 (Desilver, 2017, p. 1).

Since the beginning of the democratic rule in 1999, the country has witnessed a series of security problems. These problems, no doubt, posed serious challenges to stability in policy direction in the country, which political analysts called policy summersault (Dahl, 2018). The phenomenon has also brought about politics of security to the land. Consequently, members of security agencies, such as the police, immigration, Department of State Security (DSS), Customs and the army who are saddled with the responsibility of defending the territorial integrity of the nation, have become culpable of breaching the security protocol. This has remained a herculean task in Nigerian politics, especially in protecting the popular wish of the electorate.

The paper adopts a critical analysis of the role of the military in the democratic process in Nigeria since 1999. Among the issues analysed are the role of the role of the military in crises such as Militants in Niger-Delta, Odua Peoples' Congress in the South West, Bakassi Boys in the South East, and the Egbesu boys in the South-South. While the use of political goons eventually translated to the monster of Boko Haram has ravaged the Northern part of the country.

The democracy, which is seen as the main driver of the developmental process in advance countries of the world, is becoming a monster in Nigeria. The politics is no longer guarantee security in the society; security has become an instrument of settling political scores in every part of the country. It has become a campaign slogan of political leaders to secure power. Politics of security has taken relegated developmental issues to the background in Nigeria.

In of this, is military as an institution devoid of political bias in its daily activities under democratic government since the beginning of democracy in 1999? Moreso, has democracy brought Nigerians together for the purpose of sincerity that could drive genuine required development and guarantee lasting peace? These are germane issues in this study. In order to have a clear understanding of the democratic process in Nigeria, few keywords are well analyzed below. 


\section{Conceptual Clarification}

Democracy: The word democracy is very central in the analysis of the subject matter. Democracy is literally known as rule by the people. The term is derived from the Greek word demokratia which was coined from dẻmos, meaning people and Kratias means (rule) in the middle of the 5th century BCE which connotes the political system in some Greek city-states, particularly Athens (Mariam-Webster 2018, p. 10).

Democracy is the acceptable system of government by the majority. This is essentially a definition coined by Abraham Lincoln who defined democracy as the government of people by the people and for the people (Appadorai, 2004). It is known as the rule of majority protecting the interest of minority in the society. In other words, it is a system of government by the whole population or all the eligible members of state. In the light of this, the Mariam-Webster dictionary defines democracy as a government of the people by the people. A government in which the supreme power is vested in the people and exercised by them directly or indirectly through a system of representation usually involving periodically held free elections.

Security: The term security simply means freedom from worries of loss. Security connotes defence against internal and external aggression, malicious and accidental threats (Colllins, 2018). Defence comprises detection, prevention and response to threats through the use of security policies. Security also serves as a guarantee for the protection of lives and property within the confine of legal segmented territories. The military is the institution constitutionally established for the purpose of providing peace and security to citizens.

The Military: the Military or armed force is a professional institution formally authorised by a sovereign state to use lethal or deadly force and weapons to the interests of the state. The army is divided into three segments namely: Army, Navy and Air force (Prasuhn, 2018). The people recruited into the institution are given power to defend the sovereignty of a state. The military protects and defend the territorial integrity of its country by defending it from internal and external aggression, terrorists, anarchists, arsonists, etc. Adequate security in any society brings about development.

Electioneering: Electioneering is the process of mobilisation and sale of manifestoes by candidates. The process provides an opportunity to political parties to sell their manifestoes to the electorate highlighting what they will achieve if voted into power (The Punch, 2018). Having voted into power, the behaviour of politicians in position of authority generates more crises. The action of the politicians shows that they adopt politics of security to keep larger population of society in perpetual penury rather than security of politics which guarantee development. Insecurity in Nigeria had taken minds of people away from a developmental project. Prevalent crises in the land top the agenda of discussion. 
Development: The word development represents the idea of methods being found to fulfil the aspirations of a nation, group or state, in theoretical terms, the idea of development been closely connected with the idea of progress (Todaro \& Smith, 2011). Having analysed the assertion made by Todaro and Smith (2011), the idea of development in Nigeria is totally disconnect with the idea of progress because the security that would bring stability is completely absent in the context of politics in Nigeria. Development for-all creates an enabling environment for the high, middle and low classes to have peaceful and good conduct of life for co-existence. Since the inception of democracy in 1999, Nigeria has been a fractured state divided along religion and ethnic sentiment.

\section{Brief Historical Background of Military in Nigeria}

The historical account of the Nigerian Army would throw more light to its present activities under democratic government since 1999 up to 2017. The history of Nigerian Army dates back to 1863 when the Lt. Glover of Royal Navy selected 18 indigenes from the northern part of Nigeria (Tamuno, 2011). Lt. Glover organised people into local force, known as the "Glover Hausas". This set of people were trained and used by Glover as governor of Lagos to protect British trade routes around Lagos and the annexed hinterland.

In 1885, the name metamorphosed to "Hausa Constabulary". They were performing dual functions of police and military for the Lagos colonial government. As time went on, the "Hausa Constabulary" became "Lagos Constabulary". In 1901, this institution was incorporated into West Africa Frontier Force (WAFF) which was known as "Lagos Battalion". Towards the end of 1901, the Royal Niger Company under Lord Lugard had incorporated all paramilitary units in the other British dependencies into its command.

The establishment of West Africa Frontier Force (WAFF) led to the merger of all units into a regiment in each of the dependencies. The merger in Nigeria produced the Northern Nigerian Regiment and Southern Nigerian Regiment. Both Regiments had commandant respectively. While the Northern commandant was Lt. CHP Carter (1899-1901), Col. J. Wilcox headed the Southern Regiment (1900-1909). The two regiments were later used for the expedition during the annexation of Nigeria by Lord Lugard from 1901-1903.

The amalgamation of Nigeria in 1914 led to the unification of both regiments. Subsequently, the Nigerian Regiment was created. Whereas the Southern became 3rd and 4th Battalions of the Nigerian Regiment, the Northern Regiment became the ordinary infantry Battalion after the Second World War. The Nigerian Regiment was changed to Queen Own Nigerian Regiment (QONR) during the visit of Queen Elizabeth of Britain between 28 January and 15 February, 1956. The QONR eventually became the Nigerian Military Force (NMF) in the same year. On the 1st June, 1958, the British Army Council in London relinquished control of NMF to the Nigerian Government. In 1960, when Nigeria got independence, the NMF was changed to the Royal Nigerian Army (RNA). 
In 1963, when Nigeria became a Republic, the RNA became Nigerian Army. That same year, the Army changed its uniform, rank structure and instrument from those of WAFF to new ones including green Khaki uniform.

The above analysis shows the process for the formation of the military we have in Nigeria currently. Every institution is a product of its background. The creation of Nigeria began from a northern enclave with special interest from the British authority to protect their own economic activities against the local indigenes that were to be protected. The nature of transformation in the institution called the Army up to independence in Nigeria was stage managed to protect the interest of the authority in power which is against the ethics of the military which the protection of territorial integrity of the country.

More importantly, the foundation of the Nigerian political system is the architecture of military leaders under colonial and neo-colonial rules. The likes of Cecil Rhodes, Lugard, Richardson, Clifford, Bourdilion, Littletton, and McPherson were all retired Colonels and Generals of the British War Machine. These people were all compensated with posting to British colony now Nigeria either as Governor Generals or LT Governors or Residents. Their styles of governance were a military oriented rule. Consequently, the orientation of people under foreign rulers had been militarized; this orientation was inherited by the civilian rule that was not prepared to accept opposition opinion in a democratic system of government (Ademoyegun, 1981).

The foregoing development escalated security challenge when the Nigerian Government began recruitment of personnel into the rank and file of the military institution. This accounted for why sectionalism was too pronounced in the first and second military coups in Nigeria. This resulted mainly from the lopsidedness within the ranking officers. While Chief Obafemi Awolowo accused the North of taking advantage of their military stronghold on the country, the argument of who succeeds Aguyi Ironsi also became hot debate after the counter-coup of July 29, 1966. In the succession controversy that ensued, Ojukwu argued that if Ogundipe or Adebayo from the Western part of Nigeria could not be allowed to head the government. One of the three senior military officers of Igbo extraction should be made to head the government instead of General Yakubu Gowon who was a low ranking officer to the trio. Clash of interest among the high ranking military officers escalated crises, which constrained Ademola Ademoyegun (1881) to observe that:

... the clash of interest had subsided, the clash of principles had subsided, it was the clash of personalities that remained and led to the civil war and utter defeat of Biafra (p. 34).

The comment raised by Chief Obafemi Awolowo was manifested in the manner in which General Babangida acted on the result of June 12 Presidential election. General Abacha argued that the northern part of the country would not agree for a southern President to 
preside over the affairs of the country. And to satisfy the northern oligarchy, Babangida went ahead to annul the popular vote of the majority (Idowu \& Oyinlola, 2011). To placate the western part of Nigeria, the military institution under General Abdulsalami Abubakar arranged for a suitable candidate for the 1999 election from the west that could serve and protect the interest of the northern oligarchy. Eventually, Olusegun Obasanjo became the most suitable alternative thereby bringing him to power as a democratically elected President in 1999.

No matter the political manoeuvre by General Abdulsalami Abubakar which brought Obasanjo to power in order to pacify the west, the annulment of the June 12, 1993, election portrayed the military in a serious bad light. Among other effects, the action planted the seed of disunity through political ambition rather than serving and protecting the integrity of the nation which is the core mandate of the military in any society. And since May 29, 1999, security has become a major challenge in Nigeria.

\section{The Significances of Military in a Democratic Government}

Democratic institutions and democracy require the assurance that something of value will not be taken away in order to guarantee appropriate development. The feeling of safety is expected by the citizens from security agencies. And the high organs of the security agencies in any society cover the army, air force and Navy.

The Protection of territorial integrity is the main business of the military. Similarly, the importance of the military in a democratic government cannot be overemphasized being the backbone of security in any sovereign state. Its role in a democratic government is in the following areas:

i. The military guarantees smooth running of government with adequate protection of life and property. This guarantees smooth transaction of business within and outside the country for effective discharge of developmental programmes earmarked made during campaign. In view of this, the military serves as umbrella which provides shelter for democratic government.

ii. The military defends the territorial integrity of a nation and collective defence of the Alliance of their country.

iii. The military provides solid humanitarian aid to the host community and other areas where they find themselves for any assignment.

iv. The search and rescue missions are being carried out by the military to prevent insecurity in the land

v. The military provides assistance in disasters and also renders assistance whenever accident occurs where necessary

vi. The military maintains public order by providing administrative assistance, by performing protective functions and assisting the police in emerging situations (Kujat, 2010). 
Within the framework of the executive arm of the government, the Armed Forces are subordinate to political leadership which is responsible to parliamentary business as an important organ of the three arms of government in a democratic government. The appointments of Service Chiefs are being made by the executive, the confirmation lies in the hand of the highest body of the legislature which is the Senate, in the case of Nigeria. This singular process has subjected the Armed Forces authority to legislative control.

\section{The Advent of Democracy and Security Challenges in Nigeria, 1999-2018}

Since Nigeria has been created as a country, the longest democratic period is between 1999 and 2017. The period was initiated by a man who was regarded as an experienced person with vast knowledge about governance in Nigeria. He was recognised by the international community because he voluntarily relinquished power to a democratically elected government. However, his style of politics internally portrayed him as part of the problem in Nigerian politics. Many have accused him of being directly responsible for the present quagmire through political manipulations in the past.

Many have argued that the election that brought President Olusegun Obasanjo to power was fuelled mainly by the corrupt use of money and the muscling influence of retired generals. Those who have overbearing interest in preserving the present status quo seem to have adopted the General as their candidate and decided to sell him to the electorate (Idowu \& Oyinlola, 2011: 451). The candidature of Chief Olusegun Obasanjo was seen as a wrong choice for Nigeria at that time. The real principle of democracy was relegated to the background by the Generals who sponsored him. This development continued one of his opponents to declare that the battle him and Chief Olusegun Obasanjo, was like the battle between David and Goliath. In spite of this, their rancourfree electioneering campaigns devoid of reckless mudslinging and violence. After the election, Chief Olu Falae protested against the result of the election like a democrat, who loves his fatherland.

The beginning of little crisis that snowball into different conflicts could not be far-fetched from the experience of Nigerians and their political leaders under President Ibrahim Babangida. The new President Oulsegun Obasanjo failed in two main ways: firstly, his failure to persuade those who felt cheated over the June 12,1993, election and secondly, his inability to manage the unity government he formed with other political parties like Alliance for Democracy (AD) and All Peoples Party (APP).

Under the watch of President Olusegun Obasanjo, very serious crimes against political opponents were committed. His number one Chief Law Officer (Attorney General), Chief Bola Ige, was assassinated inside his bedroom at Ibadan on 23 December, 2001. Also, a prominent politician Chief Mashal Harry was assassinated (Idowu \& Oyinlola, 2011). These were political assassinations which the country never got to their roots throughout the tenure of Obasanjo's government. 
The new dispensation also came with the constitutional problem of rigidity as it is been speculated by the political leaders and constitutional laws. For the country to move forward, there must be restructuring of the system through overhauling of the 1999 constitution which ushered in new democratic government. Among the leaders who canvassed this position was Former Senate President, Ken Nnamani. Others include Ben Nwabueze, Olisa Agabkoba, Femi Falana, etc.

It was in respect to the above agitation that, Obasanjo set up a CONFAB in 2005 to review the Nigerian constitution. The Conference came up with a different view which was later collated and forwarded to the Legislative for ratification and approval. The process was marred with selfish opinions which made National Assembly under Ken Nnamani as the President of the 5th Senate reject the whole document.

Between 1999 and 2007, the country witnessed serious crises such as Odua Peoples' Congress (OPC) agitating for recognition and respect for the culture of Yoruba in all the six States of Yorubaland namely: Oyo, Ogun, Ondo, Osun, Ekiti and Lagos. A good example could be traced to Ijebu violence which claimed about fifteen lives (Oni, 2009:7). This agitation also spread to most of the Yoruba speaking groups in Kwara and Kogi States. The question of identity was so pronounced in all parts of the country.

Apart from the OPC agitation in the West, the political unrest in places like Ondo, Oyo, Osun was very visible at that time. A good example could be traced to Ekiti State. Political unrest was as at the peak when legal battle was in progress between Kayode Fayemi of Action Congress of Nigeria and Segun Oni of Peoples Democratic Party. The ACN, tagged Segun Oni's mandate as governor of Ekiti as stolen mandate that must be recovered by all means. The long drawn legal tussle caused serious tension in Ekiti State (Makinde, 2010).

In the northern part of the country, the main focus was the agitation for the adoption and full implementation of the legal system in the North. Zamfara was a good example of the northern states that adopted Sharia in totality. This agitation generated crises all over the nineteen states of northern Nigeria. In Plateau State it generated serious crisis in 2001. The crisis did not spear Kaduna and Kano.

In other parts of Eastern Nigeria, the activity of the Bakassi Boys was at its peak at that time. The long agitation led by Isaac Adaka Boro on 23rd February 1966, resurfaced again with fresh agitation by different militia groups in the South-South under the auspice of leaders such as Asari Dokubo, Ateke Tom, Topolo Government, Henry Okar, the acclaimed leader of MASSOB, etc. These were the people armed by politicians to win elections but who were later abandoned (Peel, 2009). They moved against the Nigeria state. The act of kidnapping the oil workers began with ransom payment. This was followed by pipeline destruction. This development negatively affected oil production in the Niger Delta. 
To curtail the development, the federal government set up the Amnesty Programme during which many militants accepted to drop arms against the Nigerian state. The Amnesty programme was followed by six-month training for 20,192 ex-militants. This shows the number of armed youths that were at war with Nigeria from the south-south region alone where the seat of the nation's economy is located (Adebayo 2010).

In North-East Nigeria, the major religious conflict Nigeria is contending with today sprung up in 2002, at Zagi-Biriri village, in Tarmuwa Local Government, about 70 kilometres to the state capital (Abdulsalami \& Akombo, 2017). This group later formed a different group in 2004 which became a monster called Boko Haram today. Initially, the second group in Maiduguri was integrated into politics in 2003 but later fell out with the government then. The group went on rampage in 2009 when its leader, Muhammad Yusuf, was killed. As part of insecurity, the General Commanding Officer (GOC) of the Division, Nigerian Army, Major General Ahmadu Mohammed, escaped death as angry soldiers opened fire on his official vehicle when he came to address them at Maimalari Barracks in Maiduguri, the Bornu State capital (Abdulsalami \& Akombo, 2017). Up till date Nigeria is still grappling with the Boko Haram activities which the Nigerian government is spending a huge amount of money and human resources to contain.

The North-central states were equally affected. It was reported that in Plateau and Kaduna States, a million Nigerians were displaced as a result of the crises that erupted in the areas. Also, in Plateau State, a Senator, Gyang Dantong, and James Gyang Fulani were killed in the wake of crises rocking Plateau State (Alao, Agbese, \& Wakili, 2012:1).

Again, parts of what democracy brought to Nigeria in 1999 are religious and ethnic politics at all levels. The politicians across divides adopted religion and ethnicity as tools for campaigning. This became so pronounced in 2015 presidential election. The battle line of war was drawn between north and south-south regions of the country. While the North felt that it would not allow the incumbent president to seek re-election, the South-South region felt they have the equal right like any other regions in Nigeria. The intervention of former President Goodluck Jonathan saved Nigeria from eminent collapse by officially congratulating Muhammad Buhari even when the results of the Presidential was not officially announced by the INEC, since the ballot papers were still being counted (Adeniyi, 2017).

Since President Muhammad Buhari came to power on May 29, 2015, the economic activities have been in shamble because of mismanagement of the previous administration. The effort to revamp the economy as the cardinal objective of the Buhari's administration has not been felt by the people. Other campaign promises such as fighting corruption has not been fully won by the administration due to hiccup in the judiciary system. Insecurity has taken a new dimension in Nigeria. Herdsman attacks in different states such as Benue, Taraba, Enugu, Oyo and Kaduna is on the high side. 
The issue of insecurity in Nigeria took a new dimension towards the end of 2017 in different of states of Nigeria with unimaginable killings in all nooks and crannies of the country. The issue got bad from January, 2018. The wanton destruction of lives and property in Zamfara State has made the Executive Governor, Abdul Azeez Yari, to resign his mandate as the Chief Security Officer of his state because of the activities of cattle rustlers in Zamfara State. Meanwhile, the Minister of Defence, General Dan Ali, is from Zamfara State. The Governor claims that, he is a mere de-facto Governor without legal power to give the order to security agencies under his jurisdiction to stop killings since the Chief Security Officer obey an order from a man in Abuja who has no clear cut understanding of security challenges in his jurisdiction.

\section{The Effects of Insecurity on Socio-Economic Activities in Nigeria since 1999-2017}

The above analysis has shown the negative dividends of democracy in Nigeria since 1999. Insecurity has become a major issue because of monetisation of the democratic process which has made it possible for the money bag politicians to dictate the pace in politics. The highest bidders in politics are the people being declared by the electoral umpire as the winners. From 1999 to 2011 voting in Nigeria was mere rubber stamp event. The ruling parties at states and federal level played the politics of winners take all, which is one of the main causes of insecurity we have in the country today.

The election in Nigeria is worse than daylight robbery because the military has militarised democracy. This is done by imposing candidates of their choice. The militaristic nature of Nigeria's political culture which is built on autocratic leadership affects elections in Nigeria (Adeniyi, 2017: 24). The moment people feel that justice would not be served appropriately, they resort to violence as the last option to redress the injustice meted on them.

Nigeria is a country blessed with abundant human and material resources to drive development. Unfortunately, insecurity in the country has disrupted all facets of human life. The spate of insecurity in Nigeria increases the level of illiteracy, which reduces the relevant skills required to manage the economy in all strata of life. The spate of insecurity in the northern part of Nigeria has drastically reduced the level of literacy. It is obvious that whenever a crisis erupts, many schools are destroyed. The kidnapping of school children prevents the parents from sending their children to school. For example, according to United Nations Children's Education Fund (UNICEF), 40 percent of Nigerian children aged 6 to 11 do not attend any primary school with the northern region recording the lowest school attendance rate in the country, particularly for girls (Abubakar 2015:20). The activities of Boko Haram are causing a major setback in student enrollment in both primary and secondary schools.

Insecurity in Nigeria is causing week agricultural base, apart from the fact that Nigerians had moved away from agriculture since the oil boom of the 1970s. The few set of peo- 
ple who choose farming as their main occupation are not well secured in the village. The incessant attacks by the armed bandits and Fulani herdsmen have reduced the strength of villagers. Self-inflicted communal clashes aided by the political class have turned many villages to ghostlands. This has affected agricultural output. The general spate of insecurity in Nigeria has hindered business activities and at the same time discouraged local and foreign investors, all which prevent and retard Nigeria's socioeconomic development.

\section{Conclusion}

In conclusion, democracy cannot be wished away as a system of government in the contemporary society. It has been regarded as a system which guarantees the decision of vast majority and at the same respect the voice and opinion of minority. However, security remains an important aspect of good system of government which is the main aspect of democracy. Unfortunately, the Nigeria democracy has not yet found a common ground for security of its citizens.

The politics of security is rooted in the politics of Nigeria. This makes our democracy susceptible to constant attacks by the Western world. The number of causalities since democracy began in 1999 is too much. No ethnic nationality is excluded from the conflicts erupting from the politics of security our politicians play in the country.

The analysis has shown that, the leaders of the ruling party in Nigeria always chooses politics of security as the main item used to divert peoples' attention from developmental issues. The promise of possible infrastructural during the campaign which usually takes centre stage during campaigns is always relegated to the background on assumption of office. Ironically, the main agenda of every political party is supposed to be security and development for citizens. Very worrisomely, the military institution and other security agencies are always at the centre of this ugly politics that has no benefit. The government uses them to suppress only the crises it creates. The wait in utmost disappointment the way and manner governments give blind eyes to the crises that yield "positive dividends" to those in power and the groups they represent. Sadly, apart from the mass destruction of lives and property, the government does not give adequate compensation to families of security agents whose lives are taken in such crises.

To put an end to this ugly trend in Nigeria, the political class must play by the rule of law which is the heart of democracy. There must be a clear departure from the rule of force and fragrant disobedience to rule law. People must move away from the politics of religion and ethnicity. Gerontocracy has replaced our democracy; contractocracy should be totally disregarded in our politics. 


\section{References}

1. Abdulsalami, M. D. \& Akombo, I. E. (2017). Case Study of Conflicts in Nigeria and Their Consequences. In T. S. Ngarka and E. I. Akombo (Eds.), Selected Themes in Peace Studies and Conflict Resolution in Nigeria (pp. 55-85). Jimeta-Yola: Godswill Business Venture.

2. Abubakar, H. (2015). Nigeria: 40 Percent of Children Don't Attend Primary SchoolUNICEF. Daily Trust Newspaper, Abuja, p. 20.

3. Adebayo, S. (2010). 20,192 Ex-Militants Begin Six Months Training Today. The Punch Newspaper, p. 10.

4. Ademoyegun, A. (1981). Why We Struck, The Story of the First Nigerian Coup. Ibadan: Evans Brothers.

5. Adeniyi, O. (2017). Against the Run of Play How an Incumbent President Was Defeated in Nigeria. Yaba: Kachifo.

6. Alao, O. Agbese A., \& Wakili, I. (2012). Senator Dies in Plateau Violence. Daily Trust Newspaper, p. 1

7. Appadorai, A. (2004). The Substance of Politics. New Delhi: Oxford University Press.

8. Colllins, C. (2018). Definition of Security. Retrieved from https://www.collinsdiction ary.com/dictionary/english/security.

9. Dahl, R. A. (2018). Democracy. Encyclopedia Britannica. Retrieved from https://www. britannica.com/topic/democracy.

10. Desilver, D. (2019, May 14). Despite concerns about global democracy, nearly six-inten countries are now democratic. Pew Research Centre. Retrieved from http://www. pewresearch.org/fact-tank/2017/12/06/despite-concerns-about-global-democracynearly-six-in-ten-countries-are-now-democratic/\#.

11. Fukuyama, F. (2012). The Origins of Political Order From Pre-Human Times to the French Revolution. London: Profile Books.

12. Idowu, L. \& Oyinlola, A. (2011). TELL Courage in Print. Lagos: Diamond Publications.

13. Kujat, H. (2010). The Role of the Military in a Democracy. Address by Major General H. Kujat, GEAF, Assistant Director Plans \& Policy Division, International Military Staff.

14. Makinde, F. (2010). Tribunal: Tension Grips Ekiti as Police, SSS Warn Against Violence. The Punch Newspaper, p. 1.

15. Mariam-Webster (2018). Definition of Democracy. Retrieved from www.mariam-web ster.com/democracy.

16. Oni, A. (2009). Ijebu Violence: 15 Bodies Deposited in Motuary, Community Deserted. The Punch Newspaper.

17. Peel, M. (2009). A Swamp Full of Dollars Pipelines and Paramilitaries at Nigeria's Oil Frontier. Chicago: Lawrence Hill Books.

18. Prasuhn R. (2018, March 31). What is the difference between "army" and "military"? Quora. Retrieved from https://www.quora.com/What-is-the-difference-between-ar my-and-military.

19. Schlosberg, D. (2013). Pluralism, Democracy and Political Knowledge: Robert A. Dahl and his Critics on Modern Politics. Australian Journal of Political Science, 48(3), 379381. Doi.org/10.1080/10361146.2013.824062. 
20. Tamuno, T. N. (2011). Oil Wars in the Niger Delta 1849 - 2009. Ibadan: Stirling-Hoeden Publishers.

21. The Punch (2018, June 7). Ekiti APC's Bloody Campaign Rally. The Punch. Retrieved from https://punchng.com/ekiti-apcs-bloody-campaign-rally.

22. Todaro, M. P. \& Smith S. C. (2011). Economic Development, Eleven Edition. Edinburg Gate Harlow: Pearson Education. 